\title{
A comparative study of phytate hydrolysis in the gastrointestinal tract of the golden hamster (Mesocricetus auratus) and the laboratory rat
}

\author{
BY P. J. WILLIAMS AND T. G. TAYLOR* \\ Department of Nutrition, School of Biochemical and Physiological Sciences, \\ University of Southampton, Southampton SO9 $5 \mathrm{NH}$
}

\section{(Received 28 November 1984 - Accepted 19 March 1985)}

1. The role of bacterial, dietary and intestinal phytases $(E C 3.1 .3 .8)$ in the hydrolysis of phytate was investigated in the golden hamster and rat by assaying phytase in the small intestine and by measuring the disappearance of phytate from the stomach and large intestine, using chromium oxide as an insoluble solid-phase marker.

2. It was confirmed that an active phytase was present in the proximal third of the small intestine of the rat but the enzyme was undetectable in the hamster.

3. Extensive bacterial breakdown of phytate occurred in the pregastric pouch and true stomach of the hamster with both phytase-containing and phytase-free diets, with phytate digestibilities in the true stomach ranging from $0.69-0.90$, confirming that the hamster can be regarded as a pseudo-ruminant.

4. With a phytase-free diet, the digestibility of phytate in the stomach of the rat was very low $(0.05)$ but with a wheat-based diet substantial breakdown of phytate occurred (digestibility up to 0.49 ), presumably under the influence of the cereal phytase.

5. Intestinal phytase did not appear to be of great significance in the rat but some further hydrolysis of the residual phytate probably occurred in the large intestine of both species by bacterial phytase.

Golden hamsters (Mesocricetus auratus) have a remarkable ability to hydrolyse dietary phytate in their digestive tracts, even when the diet contains a high concentration of calcium which is known to reduce the availability of phytate phosphorus in other species (Taylor, $1965,1979)$. Taylor \& Coleman (1979) reported that when hamsters were given a diet containing $10.84 \mathrm{~g} \mathrm{Ca}$ and $3.39 \mathrm{~g}$ phytate-P/ $\mathrm{kg}$ the availability of the phytate-P, i.e. the proportion of the dietary phytate hydrolysed in the digestive tract, was 0.74 compared with a value of 0.33 for rats fed on the same diet.

Phytate is hydrolysed by the enzyme phytase $(E C 3.1 .3 .8)$ and there are three sources of this enzyme in the gastrointestinal tract: the diet, the intestinal wall and the bacterial flora of the gut contents. Cereals provide the main source of phytases present in the diet but some cereal grains contain phytase only during germination. Wheat and rye contain a very active phytase but the one present in barley is considerably less active and oats and maize possess negligible enzyme activity (McCance \& Widdowson, 1944). Present evidence suggests that the phytase present in the brush-border of the mucosal cells of the duodenum plays a significant role in hydrolysing phytate in the rat and that this enzyme is identical to one or more of the isoenzymes of alkaline phosphatase (EC 3 1.3 .1) (Pileggi, 1959; Davies \& Flett, 1978). It has long been recognized that rumen bacteria hydrolyse phytate in the ruminant (Nelson et al. 1976) but it was only during the course of the present work that it became clear that bacteria play an important role in phytate breakdown in the rat, with the demonstration that germ-free rats are unable to hydrolyse phytate to any significant extent (Wise \& Gilburt, 1982).

The aims of the experiments reported here were to identify the region or regions of the gastrointestinal tract where phytate breakdown occurs in hamsters and rats and to assess 
the relative contributions to this breakdown of the three sources of phytase noted previously.

\section{EXPERIMENTAL}

Animals. Mature Wistar rats weighing $200-300 \mathrm{~g}$ and golden hamsters weighing $90-140 \mathrm{~g}$, all bred in the University animal house, were used in these experiments. The rats were stunned by a blow on the head and their necks were then dislocated. The hamsters were anaesthetized lightly with chloroform before their necks were broken.

Diets. In the first three experiments a stock wheat-based diet (PRD, Labsure Animal Foods, Poole, Dorset) was used. This diet contained (/kg): 6.5-8.0 g Ca, 5-7 g total P, 4-5 g phytate-P and $25 \mu \mathrm{g}$ cholecalciferol, the precise composition varying from batch to batch. In Expts 2 and 3 chromium oxide was added to the ground diet at a concentration of $2 \mathrm{~g} / \mathrm{kg}$ before re-pelleting. In a short-term experiment (Expt 4) a simple phytase-free diet was used containing $(\mathrm{g} / \mathrm{kg})$ : maize 500 , soya-bean flakes 383 , sucrose 100 , calcium carbonate 10 , common salt 5 and $\mathrm{Cr}_{2} \mathrm{O}_{3}$ 2: this diet was calculated to contain $5 \mathrm{~g} \mathrm{Ca} / \mathrm{kg}$.

Analytical methods. Phytate was determined in diets and gut contents by a modified version of the method of Davies \& Reid (1979). The most important modifications to the published method were as follows: $0.4 \mathrm{ml} 0.5 \mathrm{M}$-nitric acid was added to the tubes containing the standard phytate solutions as well as to the unknowns, the amount of ferric iron per tube was reduced from $50 \mu \mathrm{g}$ to $40 \mu \mathrm{g}$, the ferric thiocyanate was extracted into $7 \mathrm{ml}$ instead of $5 \mathrm{ml}$ amyl alcohol. Using this method, the standard curve was a straight line over the range 20-150 nmol phytate/tube and the coefficient of variation of replicates of five determinations ranged from 2.1 to $6.3 \%$ with a mean of $3.7 \%$. Alkaline phosphatase and phytase activities were measured in homogenates of the intestinal mucosa by the method of Davies \& Flett (1978) and expressed as $\mu \mathrm{mol} \mathrm{P}$ liberated/mg total protein per $\mathrm{h}$. The protein content of the homogenates was determined by the Biuret method. Chromium and total $\mathrm{P}$ were measured in appropriately diluted samples of nitric perchloric acid digests of diets and intestinal contents. $\mathrm{Cr}$ was determined by atomic absorption spectrophotometry at $357 \mathrm{~nm}$ using a rich air acetylene flame. The standard solutions contained $0.5-4.0 \mu \mathrm{g}$ $\mathrm{Cr} / \mathrm{ml}$ and $20 \mathrm{~g}$ ammonium chloride $/ 1$ were added to all solutions to suppress interference. P was determined by a molybdenum-blue method (Lowry \& Lopez, 1946).

Expt. 1. In this experiment, alkaline phosphatase and phytase were determined in the mucosa of the small intestine of five male rats and four male hamsters. The intestine was divided into three equal lengths in both species; section 1 included the duodenum and section 3 was adjacent to the caecum. Each section was slit longitudinally and the contents were removed by washing with assay buffer. After blotting dry, the mucosal lining was scraped off with a microscope slide and homogenized with five volumes $0.25 \mathrm{M}$-sucrose.

Expt. 2. Four male animals of each species were given the PRD diet containing $\mathrm{Cr}_{2} \mathrm{O}_{3}$ and killed $4 \mathrm{~d}$ after introducing the diet: samples of food and of digesta were taken from the stomach and large intestine for analysis for total and phytate-P and for $\mathrm{Cr}$. (The small intestines contained insufficient material for analysis.) The stomach of the hamster is divided into two well-defined sacs separated by a sphincter-like muscle (Hoover et al. 1969), the pregastric pouch and true stomach, and the contents of these two sacs were taken separately for analysis. Although this anatomical arrangement is barely apparent in the rat, the contents of the stomachs of these animals were also divided into proximal and distal sections.

Expt 3. It was recognized that the stomach contents analysed in Expt 2 may have contained faecal material, i.e. that coprophagy may have occurred, and Expt 3 was designed partially to eliminate this possibility and to follow the time-course of phytate hydrolysis in the hamster stomach. Twelve adult female hamsters and four adult male rats were fed 
Table 1. Expt 1. Alkaline phosphatase (EC 3.1.3.1) and phytase (EC 3.1.3.8) activities in the small intestine of hamsters (Mesocricetus auratus) and rats (umol phosphorus liberated/mg protein per $h$ )

(Mean values with their standard errors for four hamsters and five rats)

\begin{tabular}{|c|c|c|c|c|c|}
\hline & \multirow[b]{2}{*}{ Segment } & \multicolumn{2}{|c|}{ Alkaline phosphatase } & \multicolumn{2}{|c|}{ Phytase } \\
\hline & & Mean & $\mathrm{SE}$ & Mean & $\mathrm{SE}$ \\
\hline Hamster & $\begin{array}{l}\text { Proximal third* } \\
\text { Middle third } \\
\text { Distal third }\end{array}$ & $\begin{array}{l}1.78 \\
1 \cdot 88 \\
1 \cdot 42\end{array}$ & $\begin{array}{l}0 \cdot 42 \\
0 \cdot 35 \\
0 \cdot 30\end{array}$ & & \\
\hline Rat & $\begin{array}{l}\text { Proximal third* } \\
\text { Middle third } \\
\text { Distal third }\end{array}$ & $\begin{array}{l}5 \cdot 16 \\
1 \cdot 48 \\
0 \cdot 28\end{array}$ & $\begin{array}{l}0.50 \\
0.34 \\
0.03\end{array}$ & $\begin{array}{l}1.05 \\
0.06 \\
0.02\end{array}$ & $\begin{array}{l}0.10 \\
0.03 \\
0.02\end{array}$ \\
\hline
\end{tabular}

nd, not detected.

* Including the duodenum.

on the PRD diet containing $\mathrm{Cr}_{2} \mathrm{O}_{3}$ for $4 \mathrm{~d}$. They were then starved overnight $(16 \mathrm{~h})$ and given the same diet for $2 \mathrm{~h}$ the following morning. The animals ate voraciously and they were closely watched for the first $0.5 \mathrm{~h}$ of the feeding period, during which no coprophagy occurred. Four hamsters were killed after $0.5,1$ and $2 \mathrm{~h}$ and the rats were killed after $2 \mathrm{~h}$. Digesta were taken from both sacs of the hamster stomach and from the mixed contents of the rat stomach and analysed for total and phytate-P and for $\mathrm{Cr}$ as in Expt 2.

Expt 4. The aim of this experiment was to investigate the significance of cereal phytase in the hydrolysis of phytate in the stomachs of hamsters and rats. Four female hamsters and eight male rats were starved overnight $(16 \mathrm{~h})$ and given the phytase-free maize-soya-bean diet the next morning. The hamsters and four of the rats were killed after $1 \mathrm{~h}$ and the other four rats after $2 \mathrm{~h}$ of feeding. Food and stomach contents were analysed as in Expt 3. The phytase activities of the PRD diet and of the maize-soya-bean diet used in this experiment were checked by incubating three samples of each diet in vitro for $1 \mathrm{~h}$ using the method of Hill \& Tyler (1954).

\section{RESULTS}

Expt 1. The activities of alkaline phosphatase and phytase in the intestines of the experimental animals are shown in Table 1. There was little variation in alkaline phosphatase activity between the three regions of the small intestines in the hamster but there were large differences in enzyme activity from section to section in the rat. The greatest activity was in the proximal third, where it was approximately three times as great as in the corresponding region of the hamster. In the middle third the enzyme showed a similar activity in both species but in the distal third the activity showed a further reduction in the rat to a level one-fifth of that in the hamster.

Phytase was undetectable in the hamster intestines. In the rat, the activity of this enzyme was concentrated in the proximal third of the intestines that included the duodenum: the two distal regions possessed negligible activity.

Expt 2. Changes in the total $\mathrm{P}$ content of the digesta were similar in the two species but the overall absorption, as shown by the $\mathrm{P}: \mathrm{Cr}$ values in the colon, was greater in the rat than in the hamster (Table 2). The overall digestibility of phytate was 0.81 in the hamster and 0.62 in the rat and a high percentage of the phytate hydrolysis occurred in the stomach 
Table 2. Expt 2. The total and phytate-phosphorus content (P:chromium) of the food and digesta from different regions of the gut of the hamster (Mesocricetus auratus) and the rat (Digesta values are means with their standard errors for four animals)

\begin{tabular}{|c|c|c|c|c|c|c|}
\hline & & \multicolumn{4}{|c|}{$\mathrm{P}(\mathrm{mg} / \mathrm{mg} \mathrm{Cr})$} & \multirow{3}{*}{$\begin{array}{l}\text { Phytate } \\
\text { digestibility } \\
\text { ratio* }\end{array}$} \\
\hline & & \multicolumn{2}{|c|}{ Total } & \multicolumn{2}{|c|}{ Phytate } & \\
\hline & & Mean & $\mathrm{SE}$ & Mean & $\mathrm{SE}$ & \\
\hline \multirow[t]{5}{*}{ Hamster } & $\operatorname{Diet} \dagger$ & $3 \cdot 4$ & 0.1 & $2 \cdot 6$ & $0 \cdot 1$ & - \\
\hline & Pre-gastric pouch & $3 \cdot 4$ & 0.2 & 1.6 & $0 \cdot 2$ & $0 \cdot 38$ \\
\hline & True stomach & 1.8 & $0 \cdot 1$ & $0 \cdot 8$ & $0 \cdot 2$ & 0.69 \\
\hline & Caccum & $3 \cdot 3$ & $0 \cdot 2$ & 0.7 & 0.1 & 0.73 \\
\hline & Colon & $2 \cdot 4$ & $0 \cdot 1$ & 0.5 & $0 \cdot 1$ & 0.81 \\
\hline \multirow[t]{5}{*}{ Rat } & Diet & 3.4 & $0 \cdot 1$ & $2 \cdot 6$ & $0 \cdot 1$ & - \\
\hline & Proximal stomach & $2 \cdot 9$ & $0 \cdot 3$ & 1.6 & $0 \cdot 2$ & 0.38 \\
\hline & Distal stomach & 1.8 & 0.2 & $1 \cdot 4$ & $0 \cdot 3$ & 0.46 \\
\hline & Caecum & $2 \cdot 4$ & 0.2 & $1 \cdot 3$ & $0 \cdot 1$ & $0 \cdot 50$ \\
\hline & Colon & 1.9 & 0.1 & 1.0 & $0 \cdot 1$ & 0.62 \\
\hline
\end{tabular}

Table 3. Expt 3. Time-course study of phytate hydrolysis in the stomach of the hamster (Mesocricetus auratus), together with values for the rat $2 \mathrm{~h}$ after feeding ( $m$ g phosphorus $/ \mathrm{mg}$ chromium)

(Digesta values are means with their standard errors for four animals)

\begin{tabular}{|c|c|c|c|c|c|c|}
\hline & \multirow{3}{*}{$\begin{array}{l}\text { Period after } \\
\text { feeding } \\
\text { (h) }\end{array}$} & \multicolumn{4}{|c|}{ 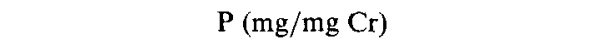 } & \multirow{3}{*}{$\begin{array}{l}\text { Phytate } \\
\text { digestibility } \\
\text { ratio* }\end{array}$} \\
\hline & & \multicolumn{2}{|c|}{ Total } & \multicolumn{2}{|c|}{ Phytate } & \\
\hline & & Mean & $\mathrm{SE}$ & Mean & $\mathrm{SE}$ & \\
\hline Diet $\uparrow$ & & $5 \cdot 3$ & $0 \cdot 1$ & 3.9 & $0 \cdot 1$ & - \\
\hline \multicolumn{7}{|l|}{ Hamster: } \\
\hline \multirow[t]{3}{*}{ Pregastric pouch } & 0.5 & 5.7 & 0.5 & 1.6 & $0 \cdot 2$ & 0.59 \\
\hline & $1 \cdot 0$ & $4 \cdot 6$ & 0.2 & 1.4 & $0 \cdot 2$ & 0.64 \\
\hline & $2 \cdot 0$ & $5 \cdot 0$ & $0 \cdot 1$ & $1 \cdot 5$ & $0 \cdot 1$ & 0.62 \\
\hline \multirow[t]{3}{*}{ True stomach } & 0.5 & $2 \cdot 6$ & 0.6 & 0.6 & $0 \cdot 1$ & 0.85 \\
\hline & $1 \cdot 0$ & 0.8 & $0 \cdot 2$ & 0.5 & $0 \cdot 1$ & 0.87 \\
\hline & $2 \cdot 0$ & $1 \cdot 5$ & 0.2 & 0.7 & $0 \cdot 1$ & 0.82 \\
\hline Rat stomach & 2.0 & $4 \cdot 2$ & 0.3 & $2 \cdot 0$ & $0 \cdot 1$ & 0.49 \\
\hline
\end{tabular}

* $\frac{\text { (Phytate-P: } \mathrm{Cr} \text { in food) }- \text { (phytate-P: } \mathrm{Cr} \text { in region) }}{\text { phytate- } \mathrm{P}: \mathrm{Cr} \text { in food }}$.

$\uparrow$ Means of eight determinations. 
Table 4. Expt 4. Phytate hydrolysis ( $m$ g phosphorus/mg chromium) in the stomach of hamsters (Mesocricetus auratus) and rats given a phytase (EC 3.1.3.8)-free diet

(Mean values with their standard errors for four animals; hamsters were killed after $1 \mathrm{~h}$, rats after 1 and $2 \mathrm{~h}$ )

\begin{tabular}{|c|c|c|c|c|c|c|}
\hline & \multirow{3}{*}{$\begin{array}{l}\text { Period } \\
\text { after } \\
\text { feeding } \\
\text { (h) }\end{array}$} & \multicolumn{4}{|c|}{$\mathrm{P}(\mathrm{mg} / \mathrm{mg} \mathrm{Cr})$} & \multirow{3}{*}{$\begin{array}{l}\text { Phytate } \\
\text { digestibility } \\
\text { ratio* }\end{array}$} \\
\hline & & \multicolumn{2}{|c|}{ Total } & \multicolumn{2}{|c|}{ Phytate } & \\
\hline & & Mean & $\mathrm{SE}$ & Mean & $\mathbf{S E}$ & \\
\hline \multicolumn{5}{|l|}{ Hamster: } & $0 \cdot 14$ & -- \\
\hline Pregastric pouch & 1 & $2 \cdot 13$ & $0 \cdot 13$ & 0.51 & 0.07 & 0.78 \\
\hline True stomach & 1 & 0.96 & 0.07 & 0.22 & 0.05 & 0.90 \\
\hline \multirow[t]{2}{*}{ Rat } & 1 & 2.84 & $0 \cdot 12$ & $2 \cdot 19$ & 0.04 & 0.05 \\
\hline & 2 & 2.89 & 0.08 & $2 \cdot 18$ & 0.07 & 0.06 \\
\hline
\end{tabular}

of both species, $85 \%$ in the hamster and $74 \%$ in the rat. The phytate- $\mathrm{P}: \mathrm{Cr}$ values in the distal region of the stomach were not significantly different $(t$ test) from those in the caecum and colon in either species, but the consistent decrease in phytate-P: Cr between the stomach and the large intestines suggests that phytate breakdown continued after the food left the stomach, either in the small or large intestines or in both. The increase in the digestibility ratio between the pregastric pouch and the true stomach of the hamster was particularly striking.

Expt 3. The results of this experiment are given in Table 3. Very little total $\mathbf{P}$ disappeared from the pregastric pouch of the hamster, even after $2 \mathrm{~h}$, but substantial losses occurred in the true stomach probably due to the leaching of soluble $\mathrm{P}$, much of which must have been derived from phytate. Rather less total $P$ was lost from the stomach of the rat $2 \mathrm{~h}$ after feeding than in the previous experiment. Period of time after feeding did not significantly affect the hydrolysis of phytate in either sac of the hamster stomach and the mean digestibility was approximately 0.62 in the pregastric pouch and 0.85 in the true stomach. These values were somewhat greater than in Expt 2, possibly because the value of Ca:phytate in the diet was higher in the latter experiment. The speed with which this breakdown occurred, $0.5 \mathrm{~h}$, was remarkable. Phytate hydrolysis in the stomach of the rat was similar to that observed in Expt 2.

After $1 \mathrm{~h}$ incubation, phytate-P: $\mathrm{Cr}$ of the PRD diet had fallen from 3.89 (SE 0.24) to 3.50 (SE $0 \cdot 18$ ), representing a loss of phytate of $10 \%$ : no phytate loss occurred when the maize-soya-bean diet was incubated in vitro.

Expt 4. The results of the feeding experiment are given in Table 4. In the rat, no loss of total $\mathrm{P}$ occurred and phytate was hydrolysed to the extent of approximately $5 \%$ both 1 and $2 \mathrm{~h}$ after feeding. In the hamster, about one-quarter of the total $\mathrm{P}$ had disappeared from the pregastric pouch and two thirds from the true stomach $1 \mathrm{~h}$ after the meal and losses of phytate were somewhat greater than in the previous experiments in which the phytasecontaining PRD diet was given, probably because the latter diet contained more $\mathrm{Ca}$ than the maize-soya-bean diet. 


\section{DISCUSSION}

The results of Expt 1 showed that the small intestines of the hamster were devoid of the enzyme phytase and we have shown in other experiments (unpublished results) that the enzyme is absent also from the cheek pouches, stomach, caecum and colon. Very substantial breakdown of the phytate present in both phytase-containing and phytase-free diets occurred in the stomach, and it is clear that bacteria must be mainly responsible for phytate breakdown in the stomach of the hamster. Hoover et al. (1969) reported that the stomach of this species, particularly the pregastric pouch, contained considerable amounts of volatile fatty acids and they considered that this animal behaved as a 'pseudo-ruminant'. They showed that the mean $\mathrm{pH}$ of the pregastric pouch was $5 \cdot 1$ compared with a value of $2 \cdot 0$ for the true stomach. The corresponding mean values for the two regions of the rat stomach are 4.8 and $3 \cdot 1$ respectively (Kunstyr, 1974). The optimum $\mathrm{pH}$ for cereal phytases is about $5 \cdot 1$, but some activity is retained down to $\mathrm{pH} 3.0$ and the enzyme is completely destroyed at pH 2.5 (Hill \& Tyler, 1954). Conditions for phytate hydrolysis are thus optimum in the pregastric pouch and this hydrolysis continued in the true stomach, presumably until secretion of the gastric juice penetrated the food mass and reduced the $\mathrm{pH}$ below that at which the enzyme is active. Some slight additional breakdown of phytate may also occur in the large intestine of the hamster (Expt 2).

Digestibility of the phytate from the PRD diet in the stomach of the rat was $0.46-0.49$ but with the phytase-free diet digestibility was only 0.05 . It appears, therefore, that microbial phytase activity is low in the rat stomach and that cereal phytase is mainly responsible for phytate breakdown in the stomach of this species. The results of Expt 2 suggest that further breakdown of phytate may have occurred in the caecum and colon of the rat, presumably under the influence of bacterial phytase. In their experiments with germ-free rats, Wise \& Gilburt (1982) recovered $100 \%$ of the dietary phytate in the faeces when a diet containing $13 \mathrm{~g} \mathrm{Ca} / \mathrm{kg}$ was given and $92 \%$ with a PRD diet containing $7 \mathrm{~g}$ $\mathrm{Ca} / \mathrm{kg}$ : the corresponding recoveries with conventional animals were $76-81$ and $25-65 \%$ respectively. Wise \& Gilburt (1982) did not discuss the role of dietary phytase in contributing to the small amount of hydrolysis that occurred in their germ-free rats given the PRD diet and it is possible that this enzyme was destroyed during the irradiation process used to sterilize their diets. If so, the $8 \%$ or so of the phytate hydrolysis in these animals was presumably carried out by their intestinal phytase. The design of the present experiments did not permit any conclusions to be drawn as to whether the additional phytate broken down between the stomach and the large intestines of the rat was brought about by intestinal or bacterial phytase and indeed, both enzymes may have contributed to this breakdown.

The main conclusions to be drawn from the present work are that phytate hydrolysis in the hamster occurs mainly in the stomach under the influence of bacterial phytase and that, with diets containing an active cereal phytase, phytate breakdown in the stomach of the rat is also considerable. Since bacterial hydrolysis of phytate in the stomach of the conventional rat is slight (present work) and since little or no hydrolysis occurs in germ-free rats (Wise \& Gilburt, 1982), it would appear that the bacteria of the large intestine are mainly responsible for phytate breakdown in conventional animals of this species when they are fed on a diet free of cereal phytase.

The authors wish to thank the Agricultural and Food Research Council for supporting this research. 


\section{REFEREN CES}

Davies, N. T. \& Flett, A. A. (1978). British Journal of Nutrition 39, 307-316.

Davies, N. T. \& Reid, H. (1979). British Journal of Nutrition 41, 579-589.

Hill, R. \& Tyler, C. (1954). Journal of Agricultural Science 44, 306-310.

Hoover, W. H., Mannings, C. L. \& Sheerin, H. E. (1969). Journal of Animal Science 28, 349-352.

Kunstyr, I. (1974). Zentralblatt für Veterinärmedizin A21, 553-561.

Lowry, O. H. \& Lopez, J. A. (1946). Journal of Biological Chemistry 162, 421-428.

McCance, R. A. \& Widdowson, E. M. (1944). Nature 153, 650.

Nelson, T. S., Daniels, L. B., Hall, J. R. \& Shields, L. G. (1976). Journal of Animal Science 42, $1509 \cdots 1512$.

Pileggi, V. J. (1959). Archives of Biochemistry and Biophysics 80, 1-8.

Taylor, T. G. (1965). Proceedings of the Nutrition Society 24, 105-112.

Taylor, T. G. (1979). In Recent Advances in Animal Nutrition-1979, pp. 23-33 [W. Haresign and D. Lewis, editors]. London: Butterworths.

Taylor, T. G. \& Coleman, J. W. (1979). British Journal of Nutrition 42, 113-119.

Wise, A. \& Gilburt, D. J. (1982). Applied and Environmental Microbiology 43, 753-756. 